\title{
Think tanks in Denmark - Media visibility and Network
}

\section{Relations}

Mark Blach-Ørsten

Nete Nørgaard Kristensen

\section{Introduction ${ }^{1}$}

Special interest think tanks have a long history in countries such as the US, Great Britain and Germany but they have only recently entered the public and political arena in Denmark. This entry is closely associated with the weakening of societal corporatism in Denmark since the 1980's and 1990's, which have necessitated that actors seeking to influence political decision making have had to find new ways of trying to shape policy making (Rommetvedt et al., 2012). Studies of special interest groups in Denmark have pointed towards three important arenas of influence for organized interest: the Parliament, the administration and the news media (Binderkrantz, 2012). However, such studies have until now not included think tanks. In this article we analyze the two most prominent advocacy think tanks in Denmark, the liberal think tank CEPOS and the social democratic think tank Economic Council of the Labor Movement (ECLM), and their influence on two of the three arenas: The media arena and the administrative arena.

Theoretically, we draw on de-corporatisation (Rommetvedt et al., 2012) and mediatization (Hjarvard, 2013; Strömbäck \& Esser, 2014), and argue that media visibility and attention have become increasingly important for political actors seeking to influence decision makers, but that corporatist networks and access to the administrative sphere continue to be important arenas of influence (Binderkrantz, 2012). The empirical study of the media arena analyses the coverage of selected think thanks in 2006 and 2013 in seven Danish newspapers, including three of the largest broadsheet newspapers, since especially national broadsheets continue to play an important role as agenda-setters in Denmark (e.g., Lund, Willig \& Blach-Ørsten, 2009). The study of the administrative arena is based on a database containing the members of all (by January 2014 active), nationally relevant boards of top corporations, state committees and councils, nationally represented interest group, and several formal and informal networks.

\footnotetext{
${ }^{1}$ This article is the product of close collaboration between the two authors, and we are equally responsible for the content. Our names are listed alphabetically.
} 


\section{De-corporatization and the new terrain for political actors}

Think tanks are a new phenomenon in a Danish political context. Although well-known both internationally and in Sweden and Norway, Denmark's first think tank was established in the early 2000s. Currently the number of thinks tanks, depending on their definition, may be as high as 34 . $^{2}$ That think tanks are now playing an increasingly important role in the Danish public and political debate (Kelstrup, 2014) is no coincidence. The traditional corporatist structure, i.e. that of integrating employers' associations, trade unions, and other interest groups in the policy making process, is in decline throughout Scandinavia. As a consequence political actors seeking to influence political decision making have had to find new and alternative ways of gaining public and political influence (Tyllström, 2013, Binderkrantz et. al., 2015). In a study on corporatism in Denmark and Norway from 1980 to 2005 Rommetvedt et al. (2012: 46) conclude that: "Interest group participation in policy preparing committees has declined dramatically since the early 1980s, and today political decisions are rarely prepared in corporatist committees." Along the same lines, Tyllström shows $(2013 ; 21)$ that: “(...) the Swedish political system (...) has undergone a significant de-corporatization since the 1990s in which corporatist institutions have lost their influence". Thus, evidence suggests that the socalled 'Scandinavian Corporatist Model' is changing fundamentally.

The process of de-corporatization has led to several important changes in political influence and decision-making. First of all, de-corporatization has occasioned what Rommetvedt et al. (2012) name 'the revival of Parliament'. This means that the national Parliaments have become more active, influential, and competitive, but also that the outcome of decision making processes has become more uncertain since the political opposition, in many instances, has succeeded in changing or amending government policy in ways that the government did not foresee or intend (Rommetvedt et al., 2012: 477). As a consequence of the revival of Parliament, civil servants in the ministries have increasingly become part of the policy preparing process. Thus, for political actors outside of government, the parliament and the ministries' de-corporatization has led to increasing uncertainty as to the outcome of parliamentary decision-making. As a consequence a new strategic terrain for seeking influence on political decision-making has emerged (Rommetvedt et al., 2012).

One part of this new terrain consists of the rise of lobbying and PR. Since Parliament and civil servants have become more powerful, it has also become more important for organized interests to

\footnotetext{
${ }^{2}$ See http://gotothinktank.com/dev1/wp-content/uploads/2014/01/GoToReport2013.pdf, p. 22 (last retrieved 19. January 2015).
} 
seek to influence public policy making via these channels. Thus, increased political lobbyism directed at civil servants, government and parliament has been observed in all Scandinavian countries (Tyllström, 2013; Rommetvedt et al., 2012).

Another consequence is the increased focus by political actors on strategic political advocacy through the news media (Binderkrantz \& Christensen, 2014; Tyllström, 2013). Advocacy can here be understood as the building of public opinion around an issue through the news media (Tyllström, 2013). This kind of advocacy includes preparing press releases and talking to journalist both off and on the record. Media advocacy is, however, often complemented with other activities, such as the direct lobbying of politicians, civil servants, etc.

A third aspect is the rise of think tanks. Both Tyllström (2013) and Kelstrup (2014) point out that Europe has seen "an explosion in think tanks" in recent years (Tyllström, 2013: 21), and the news media are one important arena for think tanks to practice political advocacy. But whereas news media advocacy by special interest groups (e.g., business groups, unions, organizations of public institutions, etc.) and, to some extent their lobbyism, have already been the focus of some Danish research (e.g., Binderkrantz, 2012, Binderkrantz et al. 2015), the rise of the think tank in the Danish political and public debate has so far been the subject of less scholarly attention, among other things due to the only recent introduction of thinks tanks in Denmark.

\section{Visibility, political influence and the news media}

The abovementioned studies as well as studies on visibility (Thompson, 1995, 2005) and the mediatization of politics (Ørsten, 2004; Hjarvard, 2013; Strömbäck \& Esser; 2014) show that with the decline of corporatism the news media as an arena of political influence has become increasingly important. Addressing the changes in the Danish corporatist structure in the late 1980s, Pedersen (1989) stated that the bargaining and decision making process that used to take place behind the closed doors of corporatist committees increasingly took place in the news media (Ørsten, 2005). Indeed, Thompson $(1995,2005)$ has argued that the growing visibility of public life is to be understood as one of the most important structural changes in modern society.

More specifically, Thompson $(1995,2005)$ outlines a general theory of mediated visibility and how the development in communication media has transformed public life from face-to-face interaction to mediated quasi-interaction, arguing that "mediated visibility is not just a vehicle through which aspects of social and political life are brought to the attention of others: it has become the principal means by which social and political struggles are articulated and carried out” (Thompson, 2005: 49). 
In much the same way the mediatization of politics thesis argues that Western societies to "an increasing degree is submitted to, or becomes dependent on, the media and their logic" (Hjarvard, 2008: 14). In fact Hjarvard (2013) argues that despite the decline of the party press in the Nordic countries during the $20^{\text {th }}$ century, a re-politicization of the news media in recent years have turned the news media into an opinion industry, meaning that "the media's contribution to the formation of public opinion becomes institutionalized as a permanent feature of modern politics, and the media no longer solely reflect politics, but become intimately involved in the very production of politics" (Hjarvard, 2013: 52).

In this new environment, political actors - politicians, spin doctors, but also trade unions, special interest groups, NGO's, business corporations, public bureaucracies, etc. - therefore center much of their activities on the news media. Binderkrantz et al. (2015), for instance, argue that special interest groups can, in theory, be active in three arenas of political influence: The administrative arena, the parliamentary arena and the media arena, but they also argue that "Politics has become increasingly mediatized leading all political actors to focus more on making a presence in the media" (Binderkrantz et. al. 2012: 121). In another study they further state that: "A prominent media presence provides an opportunity to effect or even shape the political agenda and influence the content of ongoing debates as well as political decisions.” (Binderkrantz \& Christiansen, 2013: 183).

On the subject of think tanks' access to the media arena and their media visibility, Rich \& Weaver (2000: 81) state that: "Media visibility has become an especially important priority for nongovernmental research organizations whose principal mission is to produce and promote their expertise among policymaker (...)”. But that special interest groups and think tanks are successful in gaining media attention is not only due to the structural changes in political decision making. Special interest groups and thinks tanks also possess a number of more general attributes that interact favorably with the way in which the news media as an institution (Cook, 1998; Ørsten, 2005) understands its role in society and organizes its work (Binderkrantz \& Christiansen, 2014; Rich \& Weaver, 2000).

The news media in Denmark, as in the rest of Scandinavia, act as the orchestrator and interpreter of the public and political debate (Allern \& Blach-Ørsten, 2011). A clear political priority given to public service television as well as direct and in-direct state subsidies for the press have made the news media in Scandinavia less vulnerable to technological and economic changes compared to, for instance, US news media (Blach-Ørsten, 2014). Thus, the news media maintain a high focus on 
national politics and national political actors as part of their political and democratic obligation to further public debate (Esmark \& Ørsten, 2006). As a consequence the news media actively compete for the 'best' political stories, a fact that many types of increasingly professionalized news sources have exploited in recent years (Allern, 2001; Kristensen, 2004; Blach-Ørsten, 2014).

It is the special interest groups' and think tanks' ability to assume this role of professional news sources that both national and international studies point to as one of the reasons why both kinds of political actors have been so successful in gaining media attention (Rich \& Weaver, 2000; Binderkrantz \& Christiansen, 2014). Evidence suggest that think tanks and special interest groups 'simply' represent new sources of information or new voices in the public debate to the news media, and thus may contribute to a more varied, informed political debate. Pautz (2011: 426), for example, argues that: "Think-tank analysts are best defined as part of the network of 'organic intellectuals' (...) among whom civil servants, technicians, policy experts or legal experts can also be found." From a news media perspective think tanks can thus be seen as a new category of 'expert sources' to the already heterogeneous group of experts and pundits characterizing contemporary journalism (e.g., Hopmann \& Strömbäck, 2010). Schlesinger supports this (2009: 3-4) when arguing that: "the connections between think tanks and news media (as well as the political system) are key because some key-think tank players are also 'media intellectuals'. The practice of think tankery is above all about the mediation of ideas (...)".

However, not all special interest groups or think tanks receive the same amount of media attention, since resources play an important role in the quest for media access and visibility (Binderkrantz \& Christiansen, 2014; Rich \& Weaver, 2000). Furthermore, the ideology or political dispositions of news media may influence the distribution of attention to various think tanks. Rich \& Weaver (2000) find some correlation between American newspapers' ideological standpoint and the think tanks they favor. Binderkrantz \& Christiansen (2014) also find that despite the death of the party press in Denmark, left leaning and right leaning newspapers favor different interest groups, with the left leaning newspapers favoring unions and right leaning newspapers favoring business groups. This exemplifies Hjarvard's (2013) argument of the re-politicization of the Danish news media.

Thus, changing political circumstances ('intra-political') and changing relations between politics and media ('extra-political') have paved the way for the emergence of think tanks in a Danish context. However, these same circumstances potentially entail that the political access and media access, gained by different think tanks, may vary considerably. 


\section{The Danish study: Think tank typology, research design and research questions}

\section{Typology of Danish think tanks, and the think tanks included in this study}

'Think tank' is a heterogeneous concept, because a variety of special interest groups, NGOs and grassroots all proclaim themselves as such. Indeed defining what a think tank is, and drawing the line between think tanks and other types of institutions and actors, are at the centre of existing literature (Kelstrup, 2014). While much of this literature concerns the US and is therefore biased towards the American debate and conceptualization of the subject, Kelstrup (2014: 21), writing on think tanks in an European context, suggests that think tanks can be identified as follows: 1) "Think tanks are organisations with a physical headquarter (sic)." 2) “Think tanks claim some degree of autonomy." 3) "Think tanks attempt to exert influence on public policy, understood broadly as courses of action adopted and pursued by political decisions-makers." 4) "Think tanks are active in mobilizing research with relevance for public policy by displaying a certain level of activity whether by conducting events, publishing or wielding media impact.” In more detail, McGann \& Sabatini (2011: 4) argue that the functions of think tanks include:

\footnotetext{
"mediating between government and public; identifying, articulating and evaluating current or emerging issues, problems, or proposals; transforming ideas and problems into policy issues; serving as an informed and independent voice in policy debates; and providing a constructive forum for exchange of ideas and information between key stakeholders in the policy formulation process".
}

Among the organizations that may, according to these characteristics, be acknowledged as think tanks, there are typically three types: ${ }^{3}$ Advocacy think tanks, universities without students, and partyaffiliated think tanks. Whereas universities without students are the oldest type of think tanks internationally, the advocacy think tank is a newcomer (Stone, 1991,1996; Kelstrup, 2014: 37).

In Denmark, most think tanks are relatively new and can be defined as advocacy think tanks for instance CEPOS, CEVEA, and KRAKA, which are all included in this study More specifically, Center for Political Studies/CEPOS, founded in 2004/2005 by business people, cultural personalities, and politicians, frames itself as an independent liberal think tank (http://cepos.dk/content/about-cepos

\footnotetext{
${ }^{3}$ Kelstrup (2014) proposes a fourth type of think tank, 'the policy think tank'. This category is not found in the international literature, and differs, it seems, only slightly from the well-known category of advocacy think tank.
} 
, last retrieved January 19 2015). This American inspired think tank has popularised the term in a Danish context and, more importantly, made way for competing or opposing, left-wing think tanks such as CEVEA and KRAKA. CEVEA was founded in 2008 as an independent center-left think tank (http://cevea.dk/english, last retrieved January 19 2015), while $K R A K A$, founded in 2011, also as an independent think tank, aims to "securing the future Danish Welfare state" (http://kraka.dk/om_kraka, our translation, last retrieved January 19 2015). In Kelstrup's (2014) definition the Economic Council of the Labor Movement (ECLM) started out as a party-affiliated organization, founded in 1936 with close ties to the Danish Trade Unions. However, since such organizations enjoy little credibility in the Danish public, it has moved towards being an advocacy-think tank with a clear focus on professional media strategies (http://www.ae.dk/english, last retrieved January 19 2015).

Thus, these four think tanks are included in this study, because all of them may be considered advocacy think tanks - the most dominating type of think tanks in Denmark, and because two of them (ECLM and CEPOS) have existed in the full period of our study (2006-2013), while the other two (CEVEA and KRAKA) are new-comers, exemplifying the recent emergence and growth of advocacy think tanks in a Danish context.

\section{Arenas of influence and samples}

In line with Binderkrantz \& Christiansen's (2014) argument of special interest groups acting in three arenas of political influence (the administrative, the parliamentary and the media arena), we analyze the influence of think tanks in two of these arenas: The media arena and the administrative arena. Since special interest groups are still invited to participate in the legislative process in the parliamentary arena, this arena is of continuous importance to the study of special interest groups. However, think tanks are not recognized in this way and are not a formal part of legislative processes. Thus, if think tanks want to influence politics, they have to go through the other two arenas.

In the empirical study of the media arena, we analyse the full yearly coverage of the four think thanks in 2006 and in 2013, covering a time-period characterised by, as mentioned, a considerable increase in think tank efforts in Denmark (Kelstrup, 2014). We include the coverage in seven Danish national newspapers - broadsheet, tabloid and niche (print-version only) ( $\mathrm{n}=2279$ news items and opinion pieces) - since especially national broadsheets continue to play an important role as agendasetters in Denmark (e.g., Lund et al., 2009). The newspapers are listed in table 1. 
Table 1: Newspapers included in the study

\begin{tabular}{|l|l|l|l|}
\hline Newspaper type & Title & Political leaning & Daily readers (Winter 2013) \\
\hline Broadsheet & Berlingske Tidende & Right-wing conservative & 200.000 \\
\hline Broadsheet & Jyllands-Posten & Right-wing liberal & 290.000 \\
\hline Broadsheet & Politiken & Centre-left & 329.000 \\
\hline Tabloid & B.T. & Center- right & 177.000 \\
\hline Tabloid & Ekstra Bladet & Center-left & 182.000 \\
\hline Niche & Information & Left-leaning & 99.000 \\
\hline Niche & Kristligt Dagblad & Christian-based & 104.000 \\
\hline
\end{tabular}

The codebook was developed as part of a larger comparative study of think tanks in the Nordic countries and a trained coder conducted the coding. Based on our theoretical framework, the empirical design was developed in order to answer the following research questions:

RQ 1: How (much) are the different think tanks represented in different printed newspapers? This question concerns the general visibility in the newspapers of the four think tanks, and whether the visibility of the individual think tank can be linked to the political leaning of the newspapers.

RQ 2: What kind of source role(s) do think tanks play in the news articles? This question is linked to the general debate on the media-sources relationship. Do the think tanks in question appear as 'neutral' expert sources, or are they clearly identified as sources with special interests.

For the study of the administrative arena we have used a database containing the members of all (by January 2014 active), nationally relevant boards. More specifically, the boards of all Danish top corporations, all state committees and councils, all boards and subcommittees of nationally represented interest group and several formal and informal networks. The unit of analysis is the appearance of a member of the board or advisory board of the selected think tanks in any of these nationally relevant boards. The database is collected by Ellersgaard \& Larsen (2014: 14) for their study of power elites in Denmark. The selection is based on 'the inclusion principle', meaning:

"(...) if a registered gathering of some sort, be it a corporation board, a social club, a royal ball, within the limits of our sociological imagination can be conceived as potentially either powerful in its own right or serve as a vehicle for social integration between elite individual, it is included (...)".

The database contains 5.332 organizations and 62.841 positions, but cannot be considered 'big data' 
according to its collectors. Instead it is middle range data, since the database is deliberately focused on Danish society (Ellersgaard \& Larsen, 2014). But in this sort of analysis relationships that could potentially influence network relations are overlooked, for example informal relationships such as friendship and kin, or relations created in the past, e.g., between actors from the same education/university (Ellersgaard \& Larsen, 2014: 18).

The aim of the network analysis is to answer the following research question:

RQ 3: How are the different think tanks connected to the administrative arena? This question concerns the fact that even though corporatism is in decline, the administrative arena is still an important arena of influence.

\section{Results: Media visibility}

The empirical data shows that all the newspapers most frequently refer to the liberal think tank CEPOS (RQ1), indicating that CEPOS has been very successful in gaining media visibility. This is especially the case in newspapers of a similar political leaning, since CEPOS is more frequently mentioned in the right-wing conservative newspaper Berlingske Tidende and the right-wing liberal newspaper Jyllands-Posten, the centre right tabloid B.T., the Christian niche newspaper Kristeligt Dagblad and the centre-left tabloid Ekstra Bladet. Only the centre-left-leaning broadsheet Politiken seems less favourable to CEPOS in terms of visibility in news items (see figure 1). Instead Politiken to a greater extent includes the left-leaning think tanks ECLM and KRAKA in the coverage compared to the other broadsheets Berlingske Tidende and Jyllands-Posten, but also compared to the other leftleaning newspapers Ekstra Bladet and Information. Politiken also favours the think tank Kraka. Thus, these findings imply a tendency of political parallelism of, especially, Danish broadsheets and ideologically or politically toned social agents.

That the liberal think tank CEPOS is by far the most visible of all the analysed think tanks is in line with international findings suggesting that liberal/conservative parties are often more successful at influencing and entering the news media. Rich \& Weaver (2000: 98-99), for example, conclude that American think tanks within the 'conservative cluster' talk with a larger collective voice than those in the 'liberal cluster'. Hopmann \& Strömbäck (2010: 955) found that in media coverage of elections "media pundits more often than not have a right-wing rather than a left-wing background". This Danish study of think tanks supports this, because even though two new left-wing think tanks 
(KRAKA and CEVEA) have entered the media arena in the analysed period (2006-2013), CEPOS continues to be the most frequently mentioned think tank in all seven newspapers in 2013, no matter their political leaning.

Figure 1: The think tank the most in focus in the analyzed newspapers

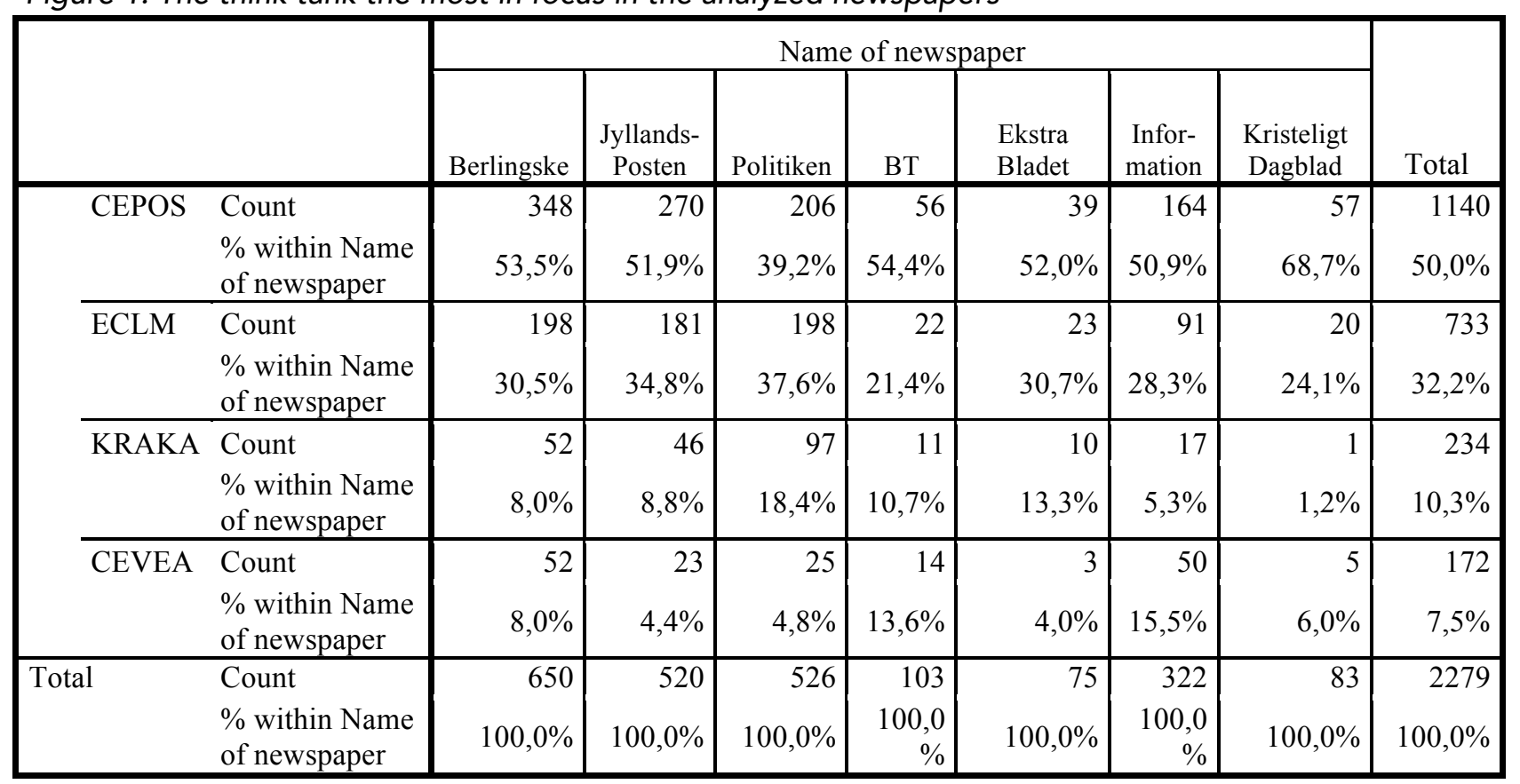

* This figure includes news stories and opinion pieces $(n=2279)$.

The successful media work of thinks tanks, of any political persuasion, is supported by the use of think tanks as sources and by the source role(s) attributed to them (RQ2). First and foremost, there has been a significant increase in the use of think tank representatives as sources in the news coverage (see figure 2): While approximately six in ten news articles in 2006 included a think tank representative as a source, this number had by 2013 increased to almost eight in ten (table not shown). ${ }^{4}$ In addition, think tanks are frequently used as the main source and increasingly so approximately every one in three main sources, quoted or referred to by the analysed newspapers, are think tank representatives (table not shown). ${ }^{5}$

\footnotetext{
${ }^{4}$ When coded for 'Is any think tank representative a source?', the answer was 'yes' in 58,4\% of the 2006-sample (272 of 466 articles) and in 76,7\% of the 2013-sample (689 of 898 articles). Only news articles were coded for this ( $\mathrm{n}=$ 1364).

${ }^{5}$ When coded for 'Main source quoted, referred to' this was a 'think tank representative' in 30,3\% of the 2006-sample (141 of 466 articles) and 37,9\% of the 2013-sample (340 of 898 articles). Only news articles were coded for this ( $\mathrm{n}=$ 1364).
} 
Figure 2: If a think tank appears a source, in what source role does the think tank appear?

\begin{tabular}{|c|c|c|c|c|c|c|c|c|c|}
\hline & & \multicolumn{7}{|c|}{ Name of newspaper } & \multirow[b]{2}{*}{ Total } \\
\hline & & Berling-ske & Jyllands-Posten & $\begin{array}{l}\text { Politi- } \\
\text { ken }\end{array}$ & BT & $\begin{array}{l}\text { Ekstra } \\
\text { Bladet }\end{array}$ & $\begin{array}{l}\text { Informa- } \\
\text { tion }\end{array}$ & $\begin{array}{l}\text { Kristeligt } \\
\text { Dagblad }\end{array}$ & \\
\hline & $\begin{array}{l}\text { Count } \\
\% \\
\text { within } \\
\text { Name of } \\
\text { newspap } \\
\text { er }\end{array}$ & 210 & 182 & 155 & 24 & $23,3 \%$ & $44,5 \%$ & $41,0 \%$ & $\begin{array}{r}687 \\
50,4 \%\end{array}$ \\
\hline $\begin{array}{l}\text { "Special } \\
\text { interest" } \\
\text { source }\end{array}$ & $\begin{array}{l}\text { Count } \\
\% \\
\text { within } \\
\text { Name of } \\
\text { newspap } \\
\text { er }\end{array}$ & 91 & 67 & 60 & 8 & $14,0 \%$ & 54 & 15 & $22,1 \%$ \\
\hline $\begin{array}{l}\text { Peripheral } \\
\text { reference }\end{array}$ & $\begin{array}{l}\text { Count } \\
\% \\
\text { within } \\
\text { Name of } \\
\text { newspap } \\
\text { er }\end{array}$ & 71 & 81 & 70 & 19 & $62,8 \%$ & $25,8 \%$ & $34,4 \%$ & 336 \\
\hline Other & $\begin{array}{l}\text { Count } \\
\% \\
\text { within } \\
\text { Name of } \\
\text { newspap } \\
\text { er }\end{array}$ & $5,3 \%$ & 12 & $2,4 \%$ & $0,0 \%$ & $0,0 \%$ & $0,0 \%$ & $0,0 \%$ & $2,9 \%$ \\
\hline Total & $\begin{array}{l}\text { Count } \\
\% \\
\text { within } \\
\text { Name of } \\
\text { newspap } \\
\text { er }\end{array}$ & $100,0 \%$ & 342 & 292 & $\begin{array}{r}100,0 \\
\%\end{array}$ & $100,0 \%$ & 182 & $100,0 \%$ & $100,0 \%$ \\
\hline
\end{tabular}

* This figure includes only news stories (news articles, news notes and feature articles), but not news analysis, editorials, op-ed/debate articles, etc. $n=1364$.

Furthermore, the think tanks are in every second case cast as (autonomous) experts and not explicitly affiliated with specific political agendas or interests (see figure 2). This is especially the case in the broadsheets, while less dominating in the niche newspapers. The broadsheets as well as the tabloids much less frequently - approximately in one in five cases - frame the think tanks as 'special interest' sources, promoting specific viewpoints. This confirms the theoretical arguments on think tanks being successful in orchestrating themselves as part of the increasingly large network of 'organic intellectuals' or 'media intellectuals' characterising contemporary media culture (e.g., Jacobs \& Townsley, 2011; Schlesinger, 2009). This dominating casting of think tanks as 'neutral' experts is confirmed by the fact that all the analysed newspapers are most often either positive or neutral to a 
proposal or initiative by the think tanks when included in a news story. In less than one in thirty cases, the newspapers apply a negative approach to the proposals or ideas presented by the think tanks (see figure 3). For example, the conservative broadsheet Berlingske has 198 news items in which the liberal think tank CEPOS (the think tank most often featured in this newspaper) is mentioned (table not shown). 38,4\% (76 news items) are positive to CEPOS, while 31,8\% (63 news items) are neutral. Regarding ECLM, the second most mentioned think tank in Berlingske, 153 news items in total make reference to this think tank of which 44,4\% (69 news items) are positive to the think tank and 32,7 $\%$ (50 news items) neutral. Also Jylland-Posten features mostly positive mention of CEPOS and ECLM, which are also the most featured think tanks in this newspaper. CEPOS has a $46 \%$ (69 news items) positive mention in the newspaper, whereas ECLM has a 43,2 \% positive mention (64 news items). However, in the more left leaning media, Politiken, Ekstra Bladet og Information, CEPOS receives the least amount of positive mention of all the think tanks covered by these newspapers. In Politiken and Information ECLM gets the most positive mention, whereas Kraka gets most positive mention in Ekstra Bladet.

Figure 3: News angle tendency

\begin{tabular}{|c|c|c|c|c|c|c|c|c|c|}
\hline & \multicolumn{7}{|c|}{ Name of newspaper } & \multirow[b]{2}{*}{ Total } \\
\hline & & $\begin{array}{l}\text { Berling- } \\
\text { ske }\end{array}$ & $\begin{array}{c}\text { Jyllands- } \\
\text { Posten }\end{array}$ & $\begin{array}{c}\text { Politi- } \\
\text { ken }\end{array}$ & BT & $\begin{array}{l}\text { Ekstra } \\
\text { Bladet }\end{array}$ & $\begin{array}{l}\text { Infor- } \\
\text { mation }\end{array}$ & $\begin{array}{l}\text { Kristeligt } \\
\text { Dagblad }\end{array}$ & \\
\hline $\begin{array}{l}\text { Positive to a } \\
\text { proposal/initiati } \\
\text { ve from the } \\
\text { think tank most } \\
\text { in focus }\end{array}$ & $\begin{array}{l}\text { Count } \\
\% \text { within Name } \\
\text { of newspaper }\end{array}$ & 165 & 151 & $\begin{array}{r}123 \\
42,1 \%\end{array}$ & $49,0 \%$ & $32,6 \%$ & $42,3 \%$ & $41,0 \%$ & $\begin{array}{r}580 \\
42,5 \%\end{array}$ \\
\hline $\begin{array}{l}\text { Negative to a } \\
\text { proposal/initiati } \\
\text { ve from the } \\
\text { think tank most } \\
\text { in focus }\end{array}$ & $\begin{array}{l}\text { Count } \\
\% \text { within Name } \\
\text { of newspaper }\end{array}$ & $1,8 \%$ & $2,9 \%$ & $3,4 \%$ & $2,0 \%$ & $7,0 \%$ & $2,7 \%$ & $1,6 \%$ & $2,7 \%$ \\
\hline $\begin{array}{l}\text { Neutral to a } \\
\text { proposal/initiati } \\
\text { ve from the } \\
\text { think tank in } \\
\text { focus }\end{array}$ & $\begin{array}{l}\text { Count } \\
\% \text { within Name } \\
\text { of newspaper }\end{array}$ & $31,3 \%$ & $40,9 \%$ & $36,3 \%$ & $29,4 \%$ & $39,5 \%$ & $41,8 \%$ & $44,3 \%$ & $37,0 \%$ \\
\hline $\begin{array}{l}\text { Irrelevant/not } \\
\text { possible to } \\
\text { decide }\end{array}$ & $\begin{array}{l}\text { Count } \\
\% \text { within Name } \\
\text { of newspaper }\end{array}$ & $\begin{array}{r}98 \\
24,9 \%\end{array}$ & $\begin{array}{r}41 \\
12,0 \%\end{array}$ & $\begin{array}{r}53 \\
18,2 \%\end{array}$ & $\begin{array}{r}10 \\
19,6 \%\end{array}$ & $\begin{array}{r}9 \\
20,9 \%\end{array}$ & $\begin{array}{r}24 \\
13,2 \%\end{array}$ & $\begin{array}{r}8 \\
13,1 \%\end{array}$ & $\begin{array}{r}243 \\
17,8 \%\end{array}$ \\
\hline Total & $\begin{array}{l}\text { Count } \\
\% \text { within Name } \\
\text { of newspaper }\end{array}$ & $\begin{array}{r}393 \\
100,0 \%\end{array}$ & $\begin{array}{r}342 \\
100,0 \%\end{array}$ & $\begin{array}{r}292 \\
100,0 \\
\% \\
\end{array}$ & $\begin{array}{r}51 \\
100,0 \%\end{array}$ & $\begin{array}{r}43 \\
100,0 \%\end{array}$ & $\begin{array}{r}182 \\
100,0 \\
\%\end{array}$ & $\begin{array}{r}61 \\
100,0 \%\end{array}$ & $\begin{array}{r}1364 \\
100,0 \\
\%\end{array}$ \\
\hline
\end{tabular}

* This figure includes only news stories (news articles, news notes and feature articles), but not news analysis, editorials, op-ed/debate articles, etc. $n=1364$. 
So, while the newspapers generally cover the think tanks positively, the newspapers tend to favour different think tanks even more according to their political leanings. This points to a re-politization of the news media with regard to the use of think tanks as sources. Thus, as is the case with most sources performing or cast as expert sources, the think tanks are only on rare occasions met by a critical framing by the analysed newspapers. The think tanks seem to have more or less unhindered access to supply the news media and the public with tailored information and agendas.

This picture is, to some extent, confirmed in the commentary articles - i.e., articles often produced by the think tanks themselves. Not surprisingly this entails an even larger share of articles, compared to the news articles, with a positive stance towards the idea or argument proposed by the think tank (see figure 4). This is especially the case in the broadsheets and in one of the tabloids, since six in ten (or more) opinion pieces in these newspapers provide a positive view towards a proposal or initiative provided by the think tanks most in focus in these newspapers. This positive favouring is, however, much less present in the niche newspapers, especially in Information. Among the opinion pieces in this newspaper we find more critical attitudes towards the think tank initiatives - that is, viewpoints most likely presented by opponents of the think tank most in focus, its proposals or ideological standpoint.

Figure 4: Commentary tendency

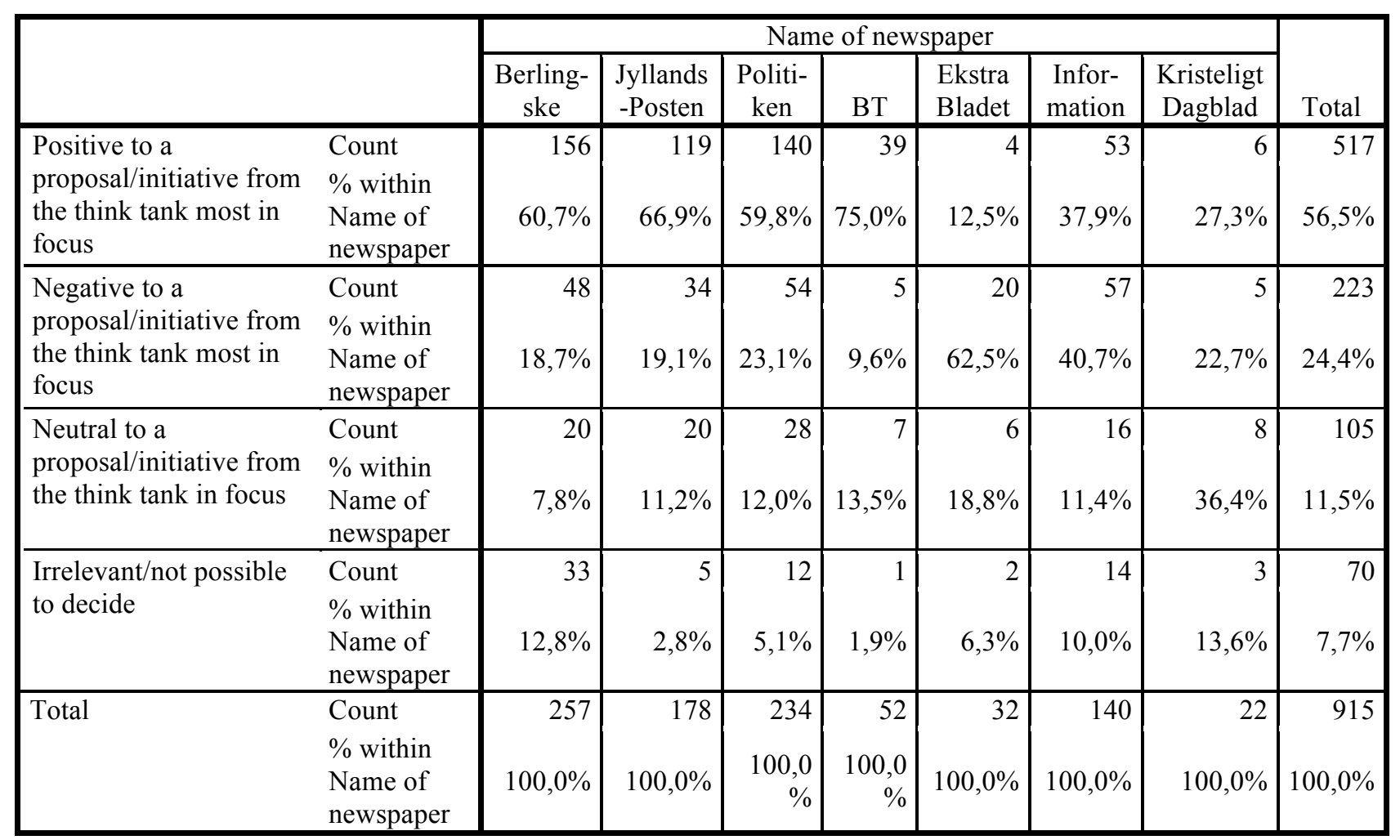

* This figure includes only opinion articles (editorials, op-ed/debate articles, etc.) but not news (news articles, news notes and feature articles), $n=915$. 
Thus, if looking for critical approaches to think tanks in the newspapers one must turn to the op-ed pages and opinionated genres rather than to the news. But, we must, more specifically, turn to the niche newspapers rather than the broadsheets for these critical voices, since especially the left-wing niche newspaper Information provides an almost equal share of positive and critical commentaries, while the broadsheets provide a more skewed picture in favour of the think tanks they give most attention. Standing apart from the rest of the sample, the tabloid, Ekstra Bladet, has the most negative comments of all newspapers. This newspaper, and especially its op-ed section, is more generally known for its often loud and negative commenting on a range of issues.

\section{Results: Network analysis}

Think tanks do not act alone in setting an agenda (Stone, 2007). But not only the news media is an important 'partner' for most think tanks. Also network relationships to donor-groups, government, organizations, corporations, etc., may assist think tanks in being recognized and gaining status as authoritative experts in society.

Turning to the analysis of the network affiliations of ECLM and CEPOS, we need to keep in mind that the unit of analysis is the appearance of a member of the board or advisory board of the selected think tank in any of the nationally relevant boards that have been included in the database.

ECLM has a high density of network relations (see figure 5), of which most include affiliations with the state, organizations, corporations, and the Danish Parliament (see figure 6). ECLM has no fewer than 106 relations in total.

The density of ECLM's relations is linked to this think tank's continuous close connections to the Danish Workers' Union and many of their members. Furthermore, the Danish Workers' Union still have a strong relationship with the Social Democratic party, which was, at the time of this analysis, leading the Danish coalition government that came into power in 2011, and which, in turn, lead to many connections between ECLM and the Danish state. However, the many network relations also show that the corporatist state, in many ways, remains. Though the same network analysis cannot be conducted at the time when the corporatist state was in its heydays, this study does suggest that the notion of de-corporatization should be considered an ongoing process, and that many of the corporatist networks remain firmly in place. 
Figure 5: ECLM's network affiliation

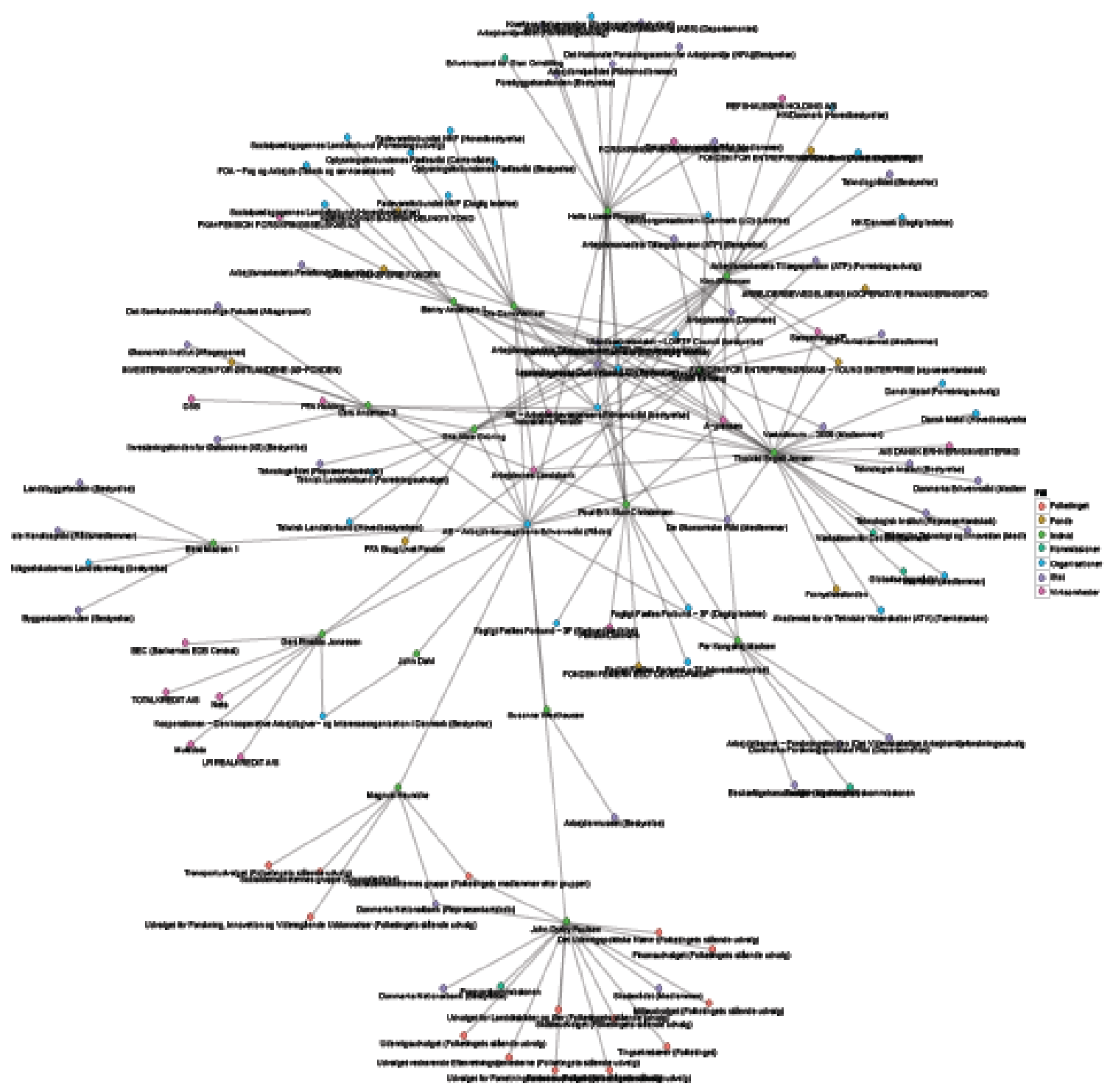


Figure 6: ECLM's most prominent network affiliations

\begin{tabular}{|l|c|c|}
\hline & Percentage & Number of relations \\
\hline Parliament & $13 \%$ & 14 \\
\hline Foundations & $8 \%$ & 9 \\
\hline Commissions & $5 \%$ & 5 \\
\hline Organizations & $26 \%$ & 28 \\
\hline State & $32 \%$ & 34 \\
\hline Corporations & $15 \%$ & 16 \\
\hline
\end{tabular}

Turning to CEPOS, it is evident that the network relations of this think tank are fewer and also, to some extent, different from those of ECLM (see figure 7 and 8). With a total of 27 network relations CEPOS is connected to a much smaller, national network than ECLM. Furthermore, CEPOS is to a much lesser extent linked to State and Parliament and has most relations to organizations and corporations. This, on the one hand, emphasises its profile as a neoliberal, market-oriented think tank. On the other hand, this also implies that successful media management and extensive visibility in the media arena does not necessarily reflect dense network relations outside the media. Indeed, it might be the other way around. CEPOS, being a newly formed liberal think tank, does not have a strong, historically based network among the actors of the Danish corporatist state but 'compensates' for this lack of network relations by focusing its resources on media relations instead. 
Figure 7: CEPOS' network relations

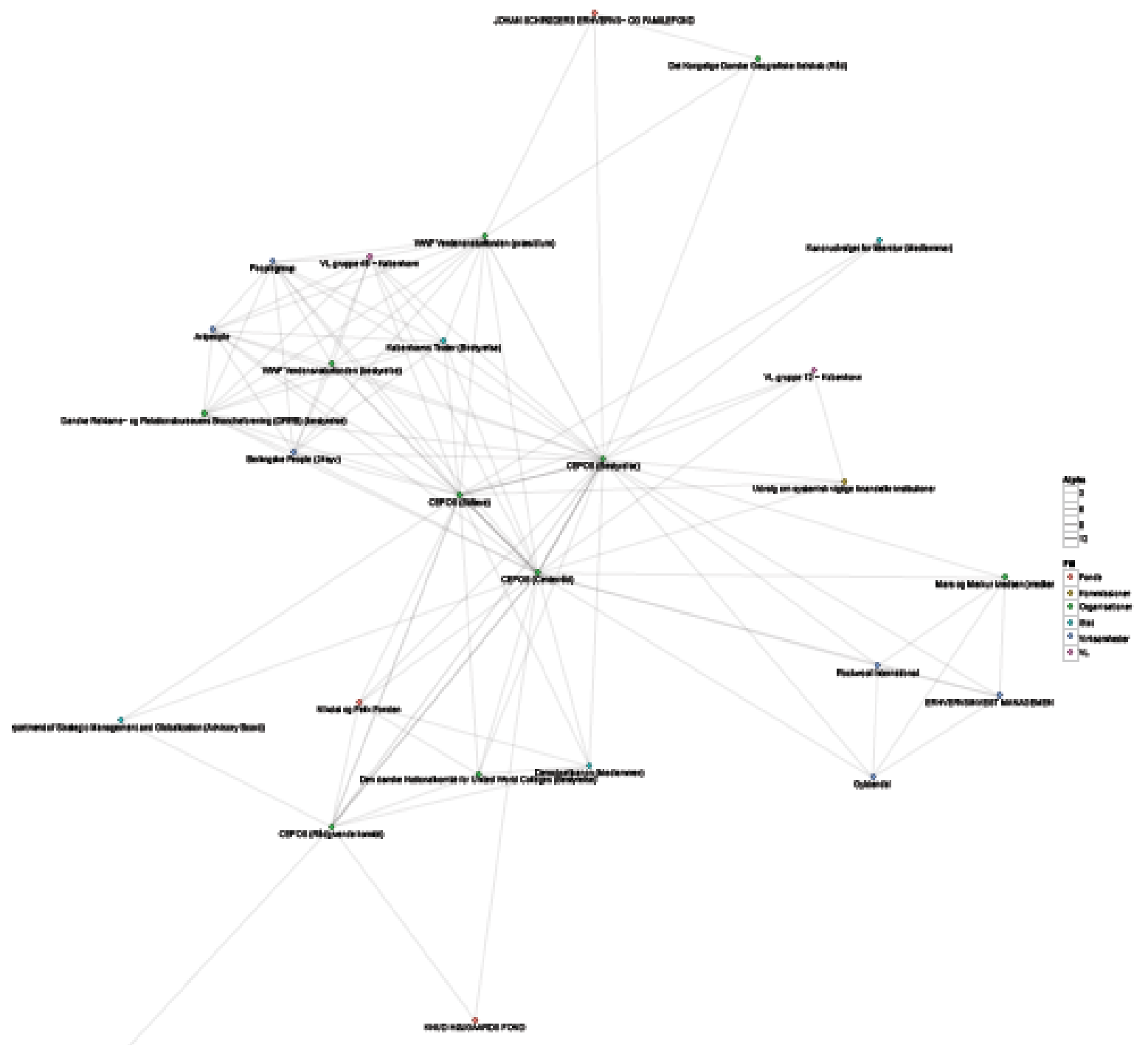

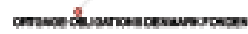


Figure 8: CEPOS' network affilications

\begin{tabular}{|l|c|c|}
\hline & Percentage & No. of relations \\
\hline Foundations & $15 \%$ & 4 \\
\hline Commissions & $4 \%$ & 1 \\
\hline Organizations & $37 \%$ & 10 \\
\hline State & $15 \%$ & 4 \\
\hline Corporations & $22 \%$ & 6 \\
\hline VL-Networks & $7 \%$ & 2 \\
\hline
\end{tabular}

\section{Conclusion}

Our analysis shows that advocacy think tanks have come to play an increasingly important role within and outside the Danish news media during the past decade. Especially, the two oldest and largest Danish think tanks, CEPOS and ECLM, seem to have caught the news media's attention as topics and sources of interest and importance. They receive almost the same amount of media coverage, yet the liberal think tank CEPOS receives more positive attention by the liberal media, while the social democratic think tank ECLM receives more positive attention by the centre left media. This confirms the tendency towards re-politization of the news media in Denmark that others have also pointed to (Binderkrantz \& Christiansen, 2014; Esmark \& Ørsten, 2006; Hjarvard \& Kristensen, 2014), and similar conclusions have been reached in a US context (Rich \& Weaver, 2000).

Furthermore, the media study shows that advocacy think tanks most often appear as 'independent' expert sources, and increasingly so, in news items rather than as 'special interest sources', despite their raison d'être of promoting particular ideologies and causes. This reflects the news media's more general tendency to prioritize a very heterogeneous flock of expert sources (e.g., Albæk, 2011), legitimised by quite varying forms of knowledge and authority (Kristensen \& From, 2015), but it also indicates that Danish think tanks have efficiently and quickly succeeded in promoting themselves publicly as providers of ('objective') expert knowledge. 
The network analysis shows that both dominating think tanks are well connected but, largely, to different spheres of society. CEPOS is mostly connected to media and private business, whereas ECLM has a much larger and broader network that links them to the state/government, private business, the unions, etc.

We can therefore conclude that think tanks are very active in Denmark, have a high media visibility and are successful in casting themselves in the news media as expert sources rather than being affiliated with specific political interests. But we can also conclude that media visibility is only one part of the equation and that the social network of the think tanks must also be taken into consideration. Thus, even though the debate on de-corporatization would suggest that the news media as an arena of influence has become the most important one, our analysis show that some of the corporatist structures are still intact and thus continues to warrant both focus and analysis.

\section{Keywords}

Denmark, mediatization, media visibility, news sources, de-corporatization, re-politicization, special interest groups, think tanks

\section{References}

Albæk, E (2011) The interaction between experts and journalists in news journalism. Journalism 12(3): 335-348.

Allern, S (2001) Flokkdyr på Løvebakken: søkelys på Stortingets presselosje og politikkens medierammer. Oslo: Pax.

Allern, S and Blach-Ørsten, M (2011) The news media as a political institution: A Scandinavian perspective. Journalism Studies 12(1): 92-105.

Binderkrantz, AS and Christiansen, PM (2014) Making it to the news. Interest groups in the Danish media. In: Franziska, O (ed.) Politische Interessenvermittlung und Medien. Baden Baden: Nomos.

Binderkrantz, AS (2012) Interest groups in the media: Bias and diversity over time. European Journal of Political Research. 51(1): 117-139.

Binderkrantz, AS, Christiansen, PM \& Pedersen, HH (2015) Interest Group Access to the Bureaucracy, Parliament and the Media. Governance 28(1): 95-112 . 
Blach-Ørsten, M (2014). The Emergence of an Increasingly Competitive News Regime in Denmark. In Kuhn, R and Nielsen, RK (eds.) Political Journalism in Transition: Western Europe in a Comparative Perspective, 93-110. London: I.B. Tauris \& Co.

Cook, TE (1998) Governing with the news: The news media as a political institution. University of Chicago Press.

Ellersgaard, CH \& Larsen, AG (2014) Identifying power elites - a social network analytis approach. paper for the Danish Sociological Conference 2014.

Esmark, A and Ørsten, M )2006) Media and Politics in Denmark. In Strömbäck, J, Ørsten, M and Aalberg, T (eds.) Political Communication in the Nordic Countries, Stockholm: Nordicom.

Gallup (2013) Loesertal [Online] Available from http://www.tns-gallup.dk/statistik/laesertal [Accessed January 19 2015]

Hjarvard, S and Kristensen, NN (2014) When media of a small nation argue for war. Media, War \& Conflict. 7(1): 51-69.

Hjarvard, S (2013) The mediatization of culture and society. Oxon: Routledge.

Hopmann, DN and Strömbäck, J (2010) The Rise of the Media Punditocracy?: Journalists and Media Pundits in Danish Election News 1994-2007. Media Culture and Society, 32(6): 943-960.

Jacobs, RN and Townsley, E (2011) The space of opinion: Media intellectuals and the public sphere. Oxford: Oxford University Press.

Kelstrup, JD (2014) Think tanks in Europe: explaining their development and variation in Germany, the United Kingdom, Denmark and at the EU-level. Roskilde University: PhD-dissertation.

Kristensen, NN (2004) Journalister og kilder-slinger i valsen?Aarhus: Ajour.

Kristensen, NN and From, U (2015) From Ivory Tower to Twitter: Heterogeneous Cultural Critics in the Media. Journalism Practice, online first; DOI: 10.1080/17512786.2015.1051370

Lund, AB, Willig, I and Blach-Østen, M (2009) Hvor kommer nyhederne fra?: Den journalistiske fødekcede i Danmark før og nu. Aarhus: Ajour.

McGann, JG and Sabatini, R (2011) Global Think Tanks. Policy Networks and Governance. Oxon: Routledge.

Pautz, H (2011) Revisiting the think-tank phenomenon. Public Policy and Administration 26(4): 419435.

Rich, A and Weaver, RK (2000) Think tanks in the US media. The Harvard International Journal of Press/Politics. 5(4): 81-103. 
Rommetvedt, H et al. (2012) Coping With Corporatism in Decline and the Revival of Parliament: Interest Group Lobbyism in Denmark and Norway, 1980-2005. Comparative Political Studies 46(6): 457-485.

Schlesinger, P (2009) Creativity and the experts New Labour, think tanks, and the policy process. The international journal of press/politics 14(1): 3-20.

Stone, D (1991) Old guard versus new partisans: think tanks in transition. Politics. 26(2): 197-215.

Stone, D (2007) Recycling bins, garbage cans or think tanks? Three myths regarding policy analysis institutes. Public Administration. 85(2): 259-278.

Strömbäck, J and Esser, F (2014) Mediatization of Politics: Towards a Theoretical Framework.In: Esser, F and Strömbäck, J (eds.) Mediatization of Politics. Understanding the Transformation of Western Democracies, 3-28. London: Palgrave Macmillan.

Thompson, JB (1995) Media and modernity: A social theory of the media. Cambridge: Polity Press.

Thompson, JB (2005) The new visibility. Theory, Culture \& Society. 22(6): 31-51.

Tyllström, A (2013) Legitimacy for Sale: Constructing a Market for PR Consultancy. Uppsala University: Doctoral Thesis.

Ørsten, M (2005) Nyhedsinstitutionen: et ny-institutionel perspektiv på den medierede politiske kommunikation. Økonomi \& Politik 78(3): 13-28.

Ørsten, M (2004) Transnational politisk journalistik. University of Roskilde: PhD-dissertation. 